University of Nebraska - Lincoln

DigitalCommons@University of Nebraska - Lincoln

\title{
Identifying Winter Forage Triticale ( $\times$ Triticosecale Wittmack) Strains for the Central Great Plains
}

\author{
Lekgari A. Lekgari \\ University of Nebraska-Lincoln \\ P. Stephen Baenziger \\ University of Nebraska-Lincoln, pbaenziger1@unl.edu \\ Kenneth P. Vogel \\ University of Nebraska-Lincoln, kvogel1@unl.edu \\ David D. Baltensperger \\ Texas A \& M, dbaltensperger@tamu.edu
}

Follow this and additional works at: https://digitalcommons.unl.edu/usdaarsfacpub

Lekgari, Lekgari A.; Baenziger, P. Stephen; Vogel, Kenneth P.; and Baltensperger, David D., "Identifying Winter Forage Triticale (×Triticosecale Wittmack) Strains for the Central Great Plains" (2008). Publications from USDA-ARS / UNL Faculty. 1961.

https://digitalcommons.unl.edu/usdaarsfacpub/1961

This Article is brought to you for free and open access by the U.S. Department of Agriculture: Agricultural Research Service, Lincoln, Nebraska at DigitalCommons@University of Nebraska - Lincoln. It has been accepted for inclusion in Publications from USDA-ARS / UNL Faculty by an authorized administrator of DigitalCommons@University of Nebraska - Lincoln. 


\title{
Identifying Winter Forage Triticale ( $\times$ Triticosecale Wittmack) Strains for the Central Great Plains
}

\author{
Lekgari A. Lekgari, P. Stephen Baenziger, ${ }^{\star}$ Kenneth P. Vogel, and David D. Baltensperger
}

\begin{abstract}
Triticale ( $\times$ Triticosecale Wittmack) is mainly used as a forage crop in the central Great Plains. A successful triticale cultivar should have high forage yield with good quality, and also high grain yield so the seed can be economically produced. The purpose of this study was to evaluate existing triticale cultivars and experimental strains for their relative value in the central Great Plains as an annual hay crop primarily for feeding to beef cattle. Two experiments (one for forage yield and one for grain yield) were planted at two locations (one representing the arid Great Plains and the second representing the or higher rainfall central Great Plains) for 2 yr. Twenty-nine triticale cultivars and strains were evaluated for forage yield and quality, and grain yield. In both experiments, year effects were significant $(P$ $<0.05)$ for all traits except grain yield; location effects were significant for forage yield, neutral detergent fiber (NDF), and acid detergent fiber. There was no location $x$ strain or year $\times$ location $\times$ strain interaction for all the quality traits indicating that triticale forage quality was stable across environments. Triticale strains differed significantly for forage yield, grain yield, NDF, acid detergent lignin, and relative feed value. However, forage of all strains had good feed quality. Three strains had high grain and forage yield, and very good relative feed value suggesting that triticale improvement for both grain and forage traits is possible.
\end{abstract}

L.A. Lekgari, P.S. Baenziger, Dep. of Agronomy and Horticulture, Univ. of Nebraska, Lincoln, NE 68583; K.P. Vogel, USDA-ARS and Dep. of Agronomy and Horticulture, Univ. of Nebraska, Lincoln, NE 68583; D.D. Baltensperger, Soil \& Crop Sciences Dep., Texas A \& M Univ., College Station, TX 77843. Received 24 Jan. 2008. *Corresponding author (pbaenziger1@unl.edu).

Abbreviations: ADF, acid detergent fiber; ADL, acid detergent lignin; IVDMD, in vitro dry matter digestibility; NDF, neutral detergent fiber; NIRS, near infrared reflectance spectroscopy; TDN, total digestible nutrients.

W INTER TRITICAle ( $\times$ Triticosecale Wittmack) is predominantly used as an annual forage crop (Harmoney and Thompson, 2005) in the Great Plains, though it can provide other economic and environmental benefits (e.g., Schwarte et al., 2006a,b; Nance et al., 2007). Triticale grain also can be used as a feed grain or to make flour for use in different products like cookies (Hede, 2001), and the plants can be used as a cover crop during winter periods where bare soils are vulnerable to erosion. Triticale is a potential crop for the cattle-producing areas of the central Great Plains. The use of winter triticale, with its early to late spring forage potential, would help extend the grazing season for a period when there is limited forage quantity and quality. The choice of an annual forage crop and cultivar may depend more on the time when the forage is critically needed, rather than differences in yield potential. However, current triticale cultivars need improvement because those with high grain yield tend to be poor for forage yield, whereas the excellent forage cultivars tend to be poor for grain yield, so the higher cost of seed for forage triticale production is an economic impediment to using triticale as a forage crop.

Published in Crop Sci. 48:2040-2048 (2008).

doi: 10.2135/cropsci2008.01.0048

(C) Crop Science Society of America

677 S. Segoe Rd., Madison, WI 53711 USA

All rights reserved. No part of this periodical may be reproduced or transmitted in any form or by any means, electronic or mechanical, including photocopying, recording, or any information storage and retrieval system, without permission in writing from the publisher. Permission for printing and for reprinting the material contained herein has been obtained by the publisher. 
The problem of seed cost could be reduced by developing forage cultivars with better grain yield. It is important to carefully select cultivars that will achieve high forage yield and quality in late fall or early spring, when additional feed is needed to reduce feed costs (Harmoney and Thompson, 2005), or that have the ability to provide forage over an extended period (Rao et al., 2000). Forage cultivars also need to be selected for high biomass yield and digestibility, as these will increase livestock performance and profitability (Mitchell et al., 2005).

Forage quality per se is a complex trait and can be best measured by animal productivity. There are several components that constitute forage quality, and they include protein concentration, the fiber content of the feed, and the digestibility of the forage. Neutral detergent fiber (NDF) is a measure of plant cell wall material, while acid detergent fiber (ADF) measures lignin and cellulose fraction as well as silica of plant material (McDonald et al., 1995). In vitro dry matter digestibility (IVDMD) is used to estimate the digestibility of plant material (Adesogan, 2002; McDonald et al., 1995).

Forage quality is affected by several factors such as the type of species, stage of crop at harvest or grazing, management practices, and climate, whereas animal productivity depends on forage intake, digestibility, and nutrient utilization efficiency (Van Soest et al., 1978; Van Soest, 1982; McDonald et al., 1995). So, feed requirements differ among different types of animals and animal production (e.g., dairy vs. beef production). Moore and Undersander (2002) indicated that relative feed value is another index used to rank forages and assign forage to animal groups according to their quality needs. Relative feed value estimates digestible dry matter and the dry matter intake potential from NDF as a percentage of body weight. Little is known regarding the selection and breeding of triticale cultivars or strains that combine good grain yield and forage yield and quality. The objectives of this study were (i) to evaluate existing triticale cultivars and experimental strains for their relative value in the central Great Plains for use as an annual hay crop for beef cattle, and (ii) to determine if there are triticale strains that have both high grain yields and forage yield and quality.

\section{MATERIALS AND METHODS Plant Material}

Two sets of triticale experiments (Exp. 1 and 2) were conducted to meet the objective of this study. The two experiments were necessary so that the grain yield and forage yield and quality could be easily assessed with mechanical harvesting equipment. Forage yield and quality are estimated using plants harvested before physiological maturity, whereas grain yield is estimated using plants harvested after physiological maturity. The forage trial (Exp. 2) was harvested after all plants had headed and begun forming seed, and Exp. 1 (variety trial) was harvested at physiological maturity. In the Central Plains region, the main reason for growing triticale for hay is to maintain beef cow herds, which do not need high quality hay, during the winter months. The primary need is for the quantity of hay and not for its quality. Quality simply has to be adequate, hence we harvested the triticale after heading to maximize forage yield.

The triticale variety trial (Exp. 1) and triticale forage trial (Exp. 2) consisted of three triticale cultivars (Trical [most likely Trical 100, an older forage triticale kept in the nursery to measure breeding progress], NE422T, and NE426GT), one wheat (Triticum aestivum L.) cultivar (Jagger in Exp. 1 and NE97426 in Exp. 2), and 26 triticale experimental strains. Of the 26 triticale experimental strains, eight were visually classified as forage types, 16 as grain types, and two as both forage and grain types. Wheat is the predominant small grain in the Great Plains; hence, Jagger and NE97426 (an awnless hay wheat) were included for comparisons.

\section{Experimental Design}

The trials were grown under rainfed conditions at two locations (Mead and Sidney, NE) for two seasons (2003-2004 and 2004-2005). The testing locations represent different growing environments in Nebraska (Peterson, 1992, Fufa et al, 2005). One is representative of the arid high plains (Sidney, NE; 41 $23^{\prime}$ $\mathrm{N}, 103^{\circ} 0^{\prime} \mathrm{W}$ with Duroc loam (fine-silty, mixed, superactive, mesic, Pachic Haplustolls) soil) and the second is representative of the higher rainfall eastern part of the Great Plains (Mead, NE; $41^{\circ} 13^{\prime} \mathrm{N}, 96^{\circ} 29^{\prime} \mathrm{W}$ with Sharpsburg silt loam [fine, smectitic, mesic Typic Argiudoll] soil). The experimental design was a randomized complete block design with three and four replications for Exp. 1 and Exp. 2, respectively. Plots were $2.4 \mathrm{~m}$ long and four rows wide with $0.30 \mathrm{~m}$ between rows. Experiment 1 was planted on 20 and 23 Sept. 2003, and on 8 Sept. and 4 Oct. 2004 at Sidney, and Mead, respectively in each year. Experiment 2 was planted on 10 and 25 Sept. 2003, and on 8 Sept. and 4 Oct. 2004 at Sidney and Mead, respectively in each year. These planting dates are considered near optimal for Nebraska and similar to those recommended in Iowa (Schwarte et al., 2006a,b).

\section{Traits Measured}

In Exp. 1, we measured flowering date which was calculated as the number of days after 30 April when $50 \%$ of the heads in a plot had extruded anthers (Mead only). Plant height was measured from the base of the plant to top of the spike excluding the awns, and grain yield was measured after harvesting all four rows. In Exp. 2, the following traits were measured: forage yield at harvest (wet basis) and tillers per square meter (only in 2005). All four rows were harvested for forage at soft dough stage using a Carter flail harvester (Carter Manufacturing Co., Inc., Brookston, IN) on 3 and 22 June 2004 and on 17 and 22 June 2005 for Mead and Sidney, respectively, in each year. At harvest all the plants were fully headed, and a sample was taken for dry matter determination and quality traits analysis. Forage yields are reported on a dry weight basis.

\section{Forage Quality Analysis}

Since triticale hay will be fed to beef cattle, forage quality analyses were conducted on all forage harvest samples. Samples for quality determination were weighed in the field, dried in a forced-air oven 
at $50^{\circ} \mathrm{C}$, and reweighed. Dry matter content was determined, and forage yield (dry matter basis) was calculated using the following equation: yield $\left(\mathrm{kg} \mathrm{m}^{-2}\right)=\{[$ plot yield + (wet wt sample) $] / 1000)$ $\times$ dry matter $\} / 2.9728$. The dried samples were ground through a 2-mm screen in a Wiley mill (Thomas-Wiley Mill Co., Philadelphia, PA) and 1-mm screen in a cyclone mill (Udy Corporation, Fort Collins, CO) in preparation for quality parameter analysis. Samples were scanned on a near infrared reflectance spectrophotometer (NIRS; Model 6500, Silver Spring, MD). The parameters estimated by NIRS were IVDMD, ADF, NDF, acid detergent lignin (ADL), and nitrogen content. Calibration samples for quality traits were chosen by cluster analysis of the reflectance data (Shenk and Westerhaus, 1991; Table 1). Calibration samples for IVDMD were replicated three times and analyzed with the ANKOM Rumen Fermenter (ANKOM Technology Corp., Fairport, NY) by the procedures described by Vogel et al (1999). Nitrogen was determined by the LECO combustion method (Model FP 428 and FP 2000, LECO Corp., St. Joseph, MI; Watson and Isaac, 1990; Bremmer, 1996). Neutral detergent fiber and ADL calibration samples were replicated twice and analyzed with the ANKOM Fiber Analyzer (ANKOM Technology Corp., Fairport, NY) using the procedures described by Vogel et al. (1999) and the ANKOM ADL procedure (ANKOM Technology_-9/99, Method for determining ADL in beakers). Calibration equations were developed by partial least squares (Shenk and Westerhaus, 1991), and IVDMD, NDF, N, ADF, and ADL were predicted for each year with a single calibration equation for each variable (Table 1). Protein concentration was estimated as the amount of Kjeldhal $\mathrm{N} \times 6.25$ (AOAC, 1960). Digestible dry matter (DDM) was estimated as $88.9-[$ ADF $(\%) \times 0.779]$. Relative feed value $(\mathrm{RFV})$ was estimated as $[\mathrm{DDM}(\%) \times$ DMI $(\%$ of body weight)]/1.29. Dry matter intake (DMI) was estimated by dividing 120 by percentage of forage NDF (Rohweder et al., 1978).

\section{Statistical Analysis}

Analyses of variances were conducted across years and locations. All data were analyzed for each trait using a PROC MIXED model (SAS Institute, 1996), which considered the locations and strains as fixed effects, and years and replications within location as random effects. Error mean squares were tested for homogeneity of variances to ensure the appropriateness of combined analysis of variances. The use of the $10 \%$ probability level, a less conservative test was considered because it was more important to identify differences for important traits that may be real than it was to declare real differences as being nonsignificant (economically Type I errors are unimportant, but Type II errors may add costs to livestock

Table 1. Near infrared reflectance spectroscopy (NIRS) statistics table for calibration equations used to predict neutral detergent fiber (NDF), acid detergent fiber (ADF), acid detergent lignin (ADL), in vitro dry matter digestibility (IVDMD), and nitrogen content $(\mathrm{N})$ of the forage.

\begin{tabular}{lrrrrrrrrrr}
\hline \multicolumn{1}{c}{2004} & \multicolumn{1}{c}{2005} \\
\hline Variable & NDF & ADF & ADL & IVDMD & N & NDF & ADF & ADL & IVDMD & N \\
Mean & 58.17 & 31.04 & 3.29 & 67.56 & 1.44 & 59.02 & 31.95 & 4.26 & 67.12 & 1.38 \\
SEC $^{+}$ & 0.42 & 0.82 & 0.13 & 1.31 & 0.04 & 0.98 & 0.71 & 0.36 & 1.37 & 0.05 \\
$R^{2}$ & 0.99 & 0.95 & 0.93 & 0.89 & 0.98 & 0.96 & 0.97 & 0.77 & 0.89 & 0.98 \\
SEP $^{\dagger}$ & 2.00 & 1.23 & 0.35 & 0.84 & 0.09 & 2.12 & 1.21 & 0.48 & 1.95 & 0.11 \\
\hline
\end{tabular}

†SEC, standard error of calibration; SEP, standard error of prediction. producers; Carmer, 1976). Simple Pearson's correlation between characters was computed from strain means across environments (years $\times$ location). The data were first analyzed with the wheat cultivars included. But due to the general poor performance of the wheat cultivars, and our interest in triticale strains, we then reanalyzed the data without the wheat cultivar(s).

\section{RESULTS AND DISCUSSION Climate}

Forage and grain yield are highly influenced by climate. For these experiments, the planting season was (due to stored moisture in the fields) assumed to begin on 2 July of each year. The previous crop at Mead was hay oats (Avena sativa L.) which were cut in late June or early July, while at Sidney, the field was fallowed. Mead had more precipitation (567 and $616 \mathrm{~mm}$ in 2003-2004 and 20042005 respectively) than did Sidney (281 and $468 \mathrm{~mm}$ in 2003-2004 and 2004-2005, respectively). In both seasons, there was a period of $20 \mathrm{wk}$ (beginning approximately 7 wk after planting) when there was little or no measurable precipitation at Sidney. This period of little precipitation coincided with a period of low temperatures and could have reduced plant development (Fig. 1 and 2). The weekly temperatures were similar at both locations in the two seasons with ranges of -15.7 to $26.6^{\circ} \mathrm{C}$ and -13.7 to $27.0^{\circ} \mathrm{C}$ for Mead in 2004 and 2005 , respectively, and -7.0 to $27.2^{\circ} \mathrm{C}$ and -12.0 to $24.4^{\circ} \mathrm{C}$ for Sidney in 2004 and 2005, respectively (Fig. 2).

\section{Experiments}

For comparison purposes, a wheat cultivar (Jagger in Exp. 1 which measured grain yield and NE97426 in Exp. 2 which measured forage yield) was included. Wheat is the predominant small grain in the Great Plains and all comparisons involving triticale initially must be made to wheat. The wheat cultivars used in this study were early in maturity compared to many triticale strains, but are representative of grain and forage wheat cultivars. They ranked last for forage yield $\left(7.92 \mathrm{Mg} \mathrm{ha}^{-1}\right)$ and second from last for grain yield $\left(2.95 \mathrm{Mg} \mathrm{ha}^{-1}\right)$. These results were similar to those of Rao et al. (2000) who found triticale biomass to be similar to or greater than that of wheat, and that the grain yield of triticale to be greater than that of wheat. In an earlier study without an additional $30 \mathrm{yr}$ of triticale breeding, Sapra et al. (1973) in the southeastern United States, also found triticale forage production to be equal to that of wheat, barley (Hordeum vulgare L.) and rye (Secale cereale L.). Triticale is traditionally planted earlier than wheat, therefore low wheat yields may reflect the early planting. Baenziger and Vogel (2003) and Baenziger 
et al. (2005) noted that the Nebraska released triticale cultivars NE422T and NE426GT were greater in both forage yield and grain yield than many commonly grown wheat cultivars, though NE426GT was much better than NE422T for grain yield. In this study, the forage quality traits of wheat cultivars were similar to those of triticale strains. NE97426 had IVDMD of $657 \mathrm{~g} \mathrm{~kg}^{-1}$, NDF of $596 \mathrm{~g} \mathrm{~kg}^{-1}$, ADF of $324 \mathrm{~g} \mathrm{~kg}^{-1}$, and protein concentration of $83 \mathrm{~g} \mathrm{~kg}^{-1}$. However, NE97426 had significantly higher dry matter content $\left(426 \mathrm{~g} \mathrm{~kg}^{-1}\right)$ than the triticale strains, most likely due to its earliness and to having more advanced grain formation at the time of harvest. Rao et al. (2000) indicated that increased grain formation improved whole plant digestibility because grain digestibility is three to four times greater than that of the stem and leaves. Due to the generally poor performance of the wheat cultivars and our interest in the triticale performance, the triticale strains were analyzed without the wheat cultivars to make comparisons among triticale strains. Hereafter, we will discuss only the data collected on the triticale strains.

The analyses of variances identified significant differences $(P<0.05)$ among years for all traits except grain yield; significant differences $(P<0.10)$ among locations for all traits except IVDMD, ADL, and relative feed value; and significant differences $(P<0.10)$ among strains for all traits except IVDMD and protein concentration (Table 2 and 3 ). The year $\times$ location interaction was significant for most traits with the exception of plant height, forage yield, and IVDMD, while year $\times$ strain was only significant for flowering date, plant height, and grain yield, and location $\times$ strain was significant for plant height, grain yield, and protein concentration $(P<0.10$; Table 2 and 3$)$. The four location-years used in this study represented the range of expected environments found in the Central Great Plains. In this study, the mean squares indicated that the years and locations were relatively important compared to strains (Table 2 and 3) as the mean squares for year and locations were more than 13.0 times greater than that for the strains. In most cases, the year $\times$ strain or location $\times$ strain mean squares were smaller than the strain mean squares, suggesting that rankings of strains across environments had little change (Gomez and Gomez, 1984). Since the strains had small or no interaction for the traits measured, only strain means over years and locations will be discussed hereafter.

Grain yield ranged from $1.49 \mathrm{Mg} \mathrm{ha}^{-1}$ to $5.13 \mathrm{Mg} \mathrm{ha}^{-1}$ at Mead in 2003-2004 and 2004-2005, respectively, and forage yield ranged from $4.73 \mathrm{Mg} \mathrm{ha}^{-1}$ at Sidney in 2003-2004 to $15.30 \mathrm{Mg} \mathrm{ha}^{-1}$ at Mead in 2004-2005 (Table 4). Despite a wide range of maturity among strains, there were limited differences in forage quality which may be due to the fact that all plants were fully headed when harvested for forage so there were limited physiological differences in maturity among strains (Table 4). Forage yields average over two years ranged from 8.41 to $10.09 \mathrm{Mg} \mathrm{ha}^{-1}$ for the triticale strains, while grain yield ranged from 2.58 to $4.24 \mathrm{Mg} \mathrm{ha}^{-1}$ (Table 5). NT02454, NT02421, and NT02419, visually classified as grain type, were among the high yielding strains for both forage $\left(10.09,10.03\right.$, and $9.51 \mathrm{Mg} \mathrm{ha}^{-1}$, respectively) and grain (4.24, 4.19, and 4.23 $\mathrm{Mg} \mathrm{ha}^{-1}$, respectively). NT02454 and NE02421 were not significantly different from the cultivar NE426GT (10.02 $\left.\mathrm{Mg} \mathrm{ha}^{-1}\right)$, but significantly greater than cultivars NE422T (9.23 $\left.\mathrm{Mg} \mathrm{ha}^{-1}\right)$ and Trical $(8.41 \mathrm{Mg}$ $\mathrm{ha}^{-1}$ ) for forage yield, and had significantly greater grain yield than NE422T (3.27 $\mathrm{Mg} \mathrm{ha}^{-1}$ ) and Trical (2.58 Mg $\left.\mathrm{ha}^{-1}\right)$, though they were not significantly different from NE426GT (4.08 $\mathrm{Mg} \mathrm{ha}^{-1}$ ). The third line, NT02419 was significantly lower for forage yield $\left(9.51 \mathrm{Mg} \mathrm{ha}^{-1}\right)$, but not 

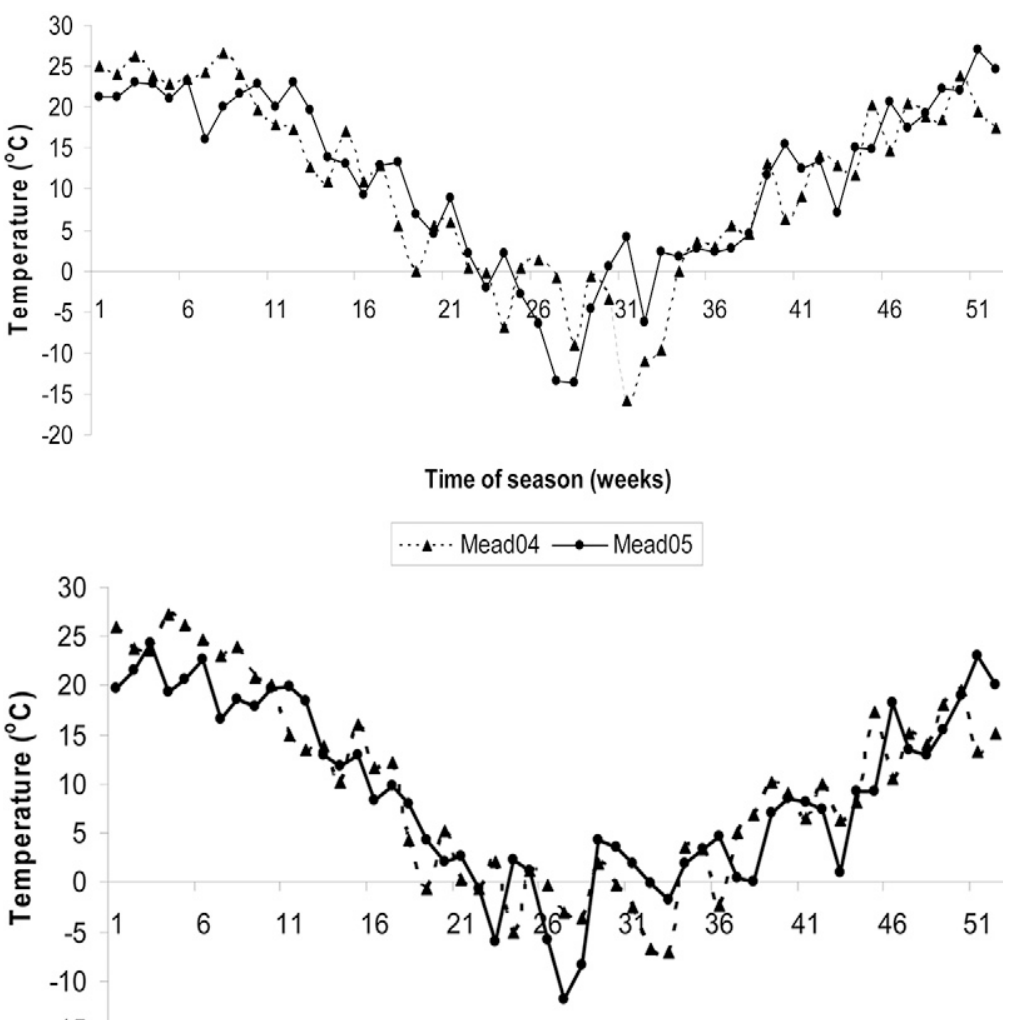

Time of season (weeks)

- -A- - Sidney04 —-Sidney05

Figure 2. Weekly temperatures recorded at Mead and Sidney, NE, during the 2003-2004 and 2004-2005 growing seasons beginning on 2 July of each year.

Table 2. Mean squares from the analysis of variance for five agronomic traits (flowering date [FD], plant height [HT], forage yield [FY], grain yield [GY], and tiller count per square meter [Tillers]) for 29 triticale cultivars and strains evaluated at Mead and Sidney, NE, in 2003-2004 and 2004-2005 seasons.

\begin{tabular}{|c|c|c|c|c|c|c|}
\hline Source & DF & $\mathrm{FD}^{\dagger}$ & $\mathrm{HT}^{\ddagger}$ & FY & GY $\ddagger$ & Tillers ${ }^{\S}$ \\
\hline Year $(Y r)$ & 1 & $669.12^{\star \star}$ & $37,488^{\star \star}$ & $599.84^{\star \star}$ & 0.26 & - \\
\hline Location (Loc) & 1 & - & $27,684^{\star \star}$ & $1984.82^{\star \star}$ & 7.39 ? & $13,020^{* *}$ \\
\hline Yr $\times$ Loc & 1 & - & 587.39 & 9.32 & $23.97^{\star \star}$ & - \\
\hline $\operatorname{Block}(\mathrm{Yr} \times \mathrm{Loc})$ & 12 & $4.50^{\star \star}$ & $206.38^{\star *}$ & $20.46^{\star \star}$ & $1.60^{\star *}$ & $6744^{\star \star}$ \\
\hline Strains (S) & 28 & $51.41^{\star *}$ & $1100.75^{\star \star}$ & $2.67^{\Uparrow}$ & $2.94^{\star *}$ & 447.38 \\
\hline $\mathrm{Yr} \times \mathrm{S}$ & 28 & $2.12^{\star \star}$ & $38.50^{\star \star}$ & 2.32 & $0.46^{\star *}$ & - \\
\hline $\operatorname{Loc} \times S$ & 28 & - & $68.27^{\star \star}$ & 2.91 & $0.92^{\star \star}$ & 257.94 \\
\hline $\mathrm{Yr} \times \operatorname{Loc} \times \mathrm{S}$ & 28 & - & $27.26^{\star \star}$ & 2.17 & $0.46^{\star *}$ & - \\
\hline Residual & 336 & 0.60 & 17.38 & 1.83 & 0.20 & 304.97 \\
\hline Mean & & 21.7 & 109.5 & 9.27 & 3.80 & 92.6 \\
\hline CV & & 3.6 & 3.8 & 14.6 & 13.2 & 18.8 \\
\hline
\end{tabular}

${ }^{* *}$ Significant at the 0.01 probability level.

${ }^{\dagger}$ Measured only at Mead over two seasons, therefore the degrees of freedom for blocks and error are 6 and 168, respectively.

†Trial had only three replications at each location, therefore the degrees of freedom for blocks and error are 12 and 224, respectively.

\$Measured only in 2004-2005.

"Significant at the 0.10 probability level. significantly different for grain yield $\left(4.23 \mathrm{Mg} \mathrm{ha}^{-1}\right)$ than NE426GT. However NT02419 was also high in relative feed value (Table 5).

The highly significant grain and forage yield differences observed among environments (years and locations) highlighted the necessity of strain evaluation across different environments in Nebraska (Tables 2 and 3; Peterson et al., 1992; Fufa et al., 2005). However, all evaluated strains had a relatively good forage quality (Table 5). Taking IVDMD to be a good estimator of total digestible nutrients (TDN), growing and finishing beef cattle or replacement heifers (weighing 249.5 to $399.2 \mathrm{~kg}$ ) will require about 81 to $100 \mathrm{~g} \mathrm{~kg}^{-1}$ protein and $600 \mathrm{~g} \mathrm{~kg}^{-1} \mathrm{TDN}$ to gain on average 0.80 to $0.85 \mathrm{~kg}$ per day (National Research Council, 1996). Those strains that had IVDMD of over $650 \mathrm{~g} \mathrm{~kg}^{-1}$ and protein concentration ranging from 80.0 to $90.4 \mathrm{~g} \mathrm{~kg}^{-1}$ (24 strains), could supply the required $500 \mathrm{~g} \mathrm{~kg}^{-1}$ TDN for average daily gains of over $0.31 \mathrm{~kg}$.

Relative feed value, though not a reflection of the nutrition of forage, is also important in estimating the value of forage, and all the strains had relative feed value ranging from 91.0 to 102.7 , which is grade 4 or above (Rohweder et al., 1978; Van Soest, 1982). This relative feed value would be suitable for maintenance of beef or dry dairy cows. Three strains (NE03T449, NT02419, and NE03T447) had relative feed value above 101 which falls in grade 3 , and all strains had a crude protein of about $80 \mathrm{~g} \mathrm{~kg}^{-1}$ which falls within the expected protein concentration for grasses (Table 5; McDonald et al., 1995). These results agree with several previous studies (Varughese et al., 1997) and indicate that triticale hay has a nutrient composition suitable for its use by beef cattle production herds.

The general lack of year $\times$ strain, location $\times$ strain, and year $\times$ location $\times$ strain interactions also indicate that there was little effect on the rankings of the triticale strains. This result may indicate that when triticale is grown for forage and harvested after flowering, forage yield and quality are stable over environments. Similar results on quality traits stability have been reported for perennial grasses (Vogel et al., 1986, 1993). However significant variation was observed for year $\times$ location interaction suggesting, as expected, the environment can have a major effect on forage quality. The arid climate of Sidney had negative impact on both grain and forage yields. Van Soest et al. (1978) indicated that warm temperatures cause plants to increase metabolism, which results in increased fiber content, which is less digestible. Also severe drought stress can cause plant dormancy resulting in high fiber and low feed value (Lardy et al., 2004) 
Table 3. Mean squares from the analysis of variance for eight quality traits (dry matter [DM], in vitro dry matter digestibility [IVDMD], neutral detergent fiber [NDF], acid detergent fiber [ADF], acid detergent lignin [ADL], crude protein [CP], and relative feed value [RFV]) of 29 triticale cultivars and strains evaluated at Mead and Sidney in 2003-2004 and 2004-2005 seasons.

\begin{tabular}{|c|c|c|c|c|c|c|c|c|}
\hline Source & DF & DM & IVDMD & NDF & ADF & ADL & $\mathrm{CP}$ & RFV \\
\hline Year (Yr) & 1 & $0.091^{\star \star}$ & $2166.19^{\star \star}$ & $544.58^{\star \star}$ & $245.66^{\star \star}$ & $32.16^{\star \star}$ & $409.62^{\star \star}$ & $371.67^{\star}$ \\
\hline Location (LOC) & 1 & $0.394^{\star \star}$ & 2.73 & $173.91^{\star *}$ & $118.22^{\star *}$ & 0.25 & $30.78^{\dagger}$ & 127.81 \\
\hline Yr $\times$ Loc & 1 & $0.485^{\star \star}$ & 8.7 & $380.93^{\star \star}$ & $333.27^{\text {** }}$ & $5.17^{\star \star}$ & $190.3^{\star *}$ & $3234.2^{\star *}$ \\
\hline Block (Yr × Loc) & 12 & $0.004^{\star \star}$ & $12.24^{\star}$ & 7.16 & 4.88 & 0.11 & $9.61^{* *}$ & 49.9 \\
\hline Strains (S) & 28 & $0.004^{* *}$ & 5.6 & $18.35^{\star}$ & $7.59^{\dagger}$ & $0.27^{\star}$ & 1.09 & $102^{\dagger}$ \\
\hline $\mathrm{Yr} \times \mathrm{S}$ & 28 & 0.0009 & 3.14 & 5.75 & 2.36 & 0.12 & 0.53 & 34.35 \\
\hline $\mathrm{Loc} \times \mathrm{S}$ & 28 & 0.0006 & 6.25 & 15.09 & 6.5 & 0.17 & $1.17^{\dagger}$ & 81.14 \\
\hline $\mathrm{Yr} \times \operatorname{Loc} \times \mathrm{S}$ & 28 & $0.002^{*}$ & 4.47 & 4.44 & 1.36 & 0.07 & 1.13 & 22.45 \\
\hline Residual & 335 & 0.0009 & 5.23 & 12.11 & 5.11 & 0.15 & 0.84 & 67.59 \\
\hline Mean & & 380.2 & 650.2 & 604.6 & 328.1 & 40.3 & 84.6 & 98.0 \\
\hline CV & & 8.0 & 3.5 & 5.8 & 6.9 & 9.7 & 10.8 & 8.4 \\
\hline
\end{tabular}

*Significant at the 0.05 probability level.

**Significant at the 0.01 probability level.

†Significant at the 0.10 probability level.

Table 4. Means and ranges of agronomic traits (flowering date [FD], plant height [HT], forage yield [FY], grain yield [GY], dry matter [DM], in vitro dry matter digestibility [IVDMD], neutral detergent fiber [NDF], acid detergent fiber [ADF], acid detergent lignin [ADL], crude protein [CP] concentration, and relative feed value [RFV]) of 29 triticale cultivars and strains grown at Mead and Sidney, NE, in 2003-2004 and 2004-2005.

\begin{tabular}{|c|c|c|c|c|c|c|c|c|c|c|c|}
\hline $\begin{array}{c}\text { Location } \\
\text { year }\end{array}$ & Statistic & HT & $\mathrm{FY}$ & GY & DM & IVDMD & NDF & ADF & ADL & CP conc. & RFV \\
\hline & & $\mathrm{cm}$ & $-M g$ & $a^{-1}-$ & - & 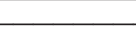 & $g$ k & $y^{-1}$ & 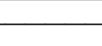 & - & \\
\hline Mead & Mean & 110.4 & 10.1 & 3.4 & 330 & 670 & 618 & 334 & 36 & 90 & 95 \\
\hline \multirow[t]{2}{*}{2004} & Range & $100-132$ & $9.1-11.2$ & $1.5-4.5$ & $300-350$ & $642-692$ & 595-658 & $320-362$ & $33-40$ & 81-104 & 86-101 \\
\hline & CV \% & 3.5 & 9.8 & 10.5 & 3.4 & 3.8 & 5.8 & 7 & 9.7 & 9.9 & 8.5 \\
\hline \multirow[t]{3}{*}{2005} & Mean & 110.4 & 12.6 & 3.9 & 369 & 629 & 579 & 332 & 44 & 84 & 102 \\
\hline & Range & $101-126$ & $10.5-15.3$ & $2.3-5.1$ & $316-421$ & $614-640$ & $552-635$ & $314-369$ & $40-50$ & 75-92 & 89-109 \\
\hline & CV \% & 9.0 & 16.3 & 15.8 & 11.1 & 2.7 & 6.7 & 7.7 & 9.4 & 7.3 & 9.4 \\
\hline \multirow[t]{4}{*}{ 2004-05 } & Mean & 110.4 & 11.4 & 3.7 & 351 & 650 & 599 & 333 & 40 & 87 & 98 \\
\hline & Range & $105-120$ & $10-12.9$ & $1.9-4.7$ & $308-385$ & $631-663$ & $574-640$ & $317-363$ & $37-44$ & $80-97$ & 88-104 \\
\hline & CV \% & 6.8 & 14.2 & 13.8 & 8.6 & 3.3 & 6.2 & 7.4 & 9.6 & 8.8 & 9 \\
\hline & LSD.05 & 7.4 & 0.4 & 0.6 & 7.8 & 5.6 & 9.7 & 6.4 & 1.0 & 2.0 & 2.3 \\
\hline \multicolumn{12}{|l|}{ Sidney } \\
\hline \multirow[t]{3}{*}{2004} & Mean & & 6.2 & 4.2 & 456 & 674 & 613 & 307 & 39 & 98 & 99 \\
\hline & Range & & $4.7-6.8$ & $3.3-5.0$ & $410-500$ & $634-697$ & $569-645$ & 288-326 & $33-43$ & 84-108 & $92-109$ \\
\hline & CV \% & & 12.2 & 6.1 & 4.1 & 4.1 & 5.2 & 5.9 & 10.4 & 9.9 & 7.4 \\
\hline \multirow[t]{3}{*}{2005} & Mean & 109.4 & 8.2 & 3.7 & 363 & 628 & 609 & 339 & 42 & 66 & 96 \\
\hline & Range & 86-132 & $6.2-9.8$ & $2.3-4.7$ & $332-400$ & $617-647$ & $592-637$ & $328-358$ & $40-45$ & $60-75$ & $89-100$ \\
\hline & CV \% & 7.3 & 15.2 & 13.2 & 10.9 & 1.8 & 1.9 & 2.4 & 4.2 & 11.4 & 2.8 \\
\hline \multirow[t]{4}{*}{ 2004-05 } & Mean & & 7.2 & 4 & 409 & 651 & 611 & 323 & 41 & 82 & 97 \\
\hline & Range & & $6.0-7.9$ & $3.2-4.6$ & $378-435$ & $635-667$ & $584-630$ & $311-335$ & $37-43$ & $72-90$ & 93-104 \\
\hline & CV \% & & 15.1 & 9.8 & 7.7 & 3.5 & 4.2 & 4.9 & 8.2 & 12.0 & 6.1 \\
\hline & LSD.05 & & 1.1 & 0.4 & 31.3 & 22.3 & 25.2 & 15.8 & 3.2 & 9.7 & 7.5 \\
\hline \multirow[t]{4}{*}{ Overall } & Mean & 110 & 9.3 & 3.8 & 380 & 650 & 605 & 328 & 40 & 85 & 98 \\
\hline & Range & $104-120$ & $8.4-10.1$ & $2.6-4.3$ & $347-405$ & $636-660$ & 584-634 & $317-348$ & $38-43$ & $80-90$ & 91-103 \\
\hline & CV \% & 7 & 17.6 & 13.2 & 8 & 3.5 & 5.8 & 6.9 & 9.7 & 10.8 & 8.4 \\
\hline & LSD.05 & 1.7 & $\mathrm{~ns}^{\dagger}$ & 0.4 & 6 & ns & 6 & ns & 7 & ns & ns \\
\hline
\end{tabular}

tns, not significant at the $P<0.05$ level. 
Table 5. Flowering date (FD), plant height (HT), forage yield (FY), grain yield (GY), dry matter (DM), in vitro dry matter digestibility (IVDMD), neutral detergent fiber (NDF), acid detergent fiber (ADF), acid detergent lignin (ADL), crude protein (CP) concentration, and relative feed value (RFV) means of top and bottom six triticale strains for forage yield at Mead and Sidney, NE, in 2003-2004 and 2004-2005 seasons. Of the three released triticale cultivars, NE426GT and Trical were among the top six and bottom six strains, respectively. The remaining triticale check cultivar (included is the check, NE422T, and which was not among the top or bottom six, and wheat cultivar were also included for comparison of experimental strains to released varieties).

\begin{tabular}{|c|c|c|c|c|c|c|c|c|c|c|c|c|}
\hline Strains & Type $^{\dagger}$ & FD & HT & FY & GY & DM & IVDMD & NDF & ADF & ADL & $\mathrm{CP}$ & RFV \\
\hline & & $d$ & $\mathrm{~cm}$ & \multicolumn{2}{|c|}{$-\mathrm{Mg} \mathrm{ha}^{-1}-$} & 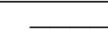 & 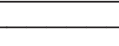 & $g k$ & & & - & \\
\hline NT02454 & GR & 20.5 & 104 & 10.09 & 4.24 & 387.8 & 635.6 & 634.5 & 348.2 & 43.1 & 83.3 & 91.0 \\
\hline NT02421 & GR & 20.3 & 108 & 10.03 & 4.19 & 404.7 & 647.2 & 611.1 & 332.7 & 41.5 & 88.8 & 96.4 \\
\hline NE426GT & GR/FO & 20.5 & 102 & 10.02 & 4.08 & 387.7 & 653.6 & 594.3 & 323.1 & 38.4 & 81.7 & 100.4 \\
\hline NE03T416 & GR & 18.8 & 99 & 9.81 & 4.09 & 400.4 & 643.6 & 607.9 & 331.1 & 40.4 & 81.7 & 97.1 \\
\hline NE03T413 & $\mathrm{FO}$ & 21.8 & 120 & 9.76 & 3.92 & 368.9 & 657.9 & 594.6 & 321.4 & 40.7 & 81.8 & 100.4 \\
\hline NE03T454 & $\mathrm{FO}$ & 26.3 & 127 & 9.61 & 3.32 & 355.7 & 654.3 & 601.2 & 325.5 & 39.6 & 86.0 & 98.8 \\
\hline NT02456 & $\mathrm{FO}$ & 23 & 112 & 9.03 & 3.33 & 367.9 & 646.1 & 614.1 & 334.5 & 40.6 & 84.6 & 95.6 \\
\hline NT01410 & GR & 19.9 & 105 & 8.95 & 4.18 & 389.9 & 647.3 & 609.7 & 330.9 & 41.1 & 84.6 & 96.7 \\
\hline NE03T447 & $\mathrm{FO}$ & 24.9 & 127 & 8.81 & 3.09 & 382.0 & 645.2 & 592.0 & 320.6 & 38.8 & 80.0 & 100.8 \\
\hline NT02410 & GR & 20.6 & 106 & 8.78 & 3.63 & 383.8 & 656.1 & 600.1 & 325.4 & 39.4 & 90.4 & 99.4 \\
\hline NE03T451 & GR & 20.4 & 104 & 8.65 & 4.09 & 381.2 & 646.5 & 599.6 & 323.7 & 38.2 & 84.1 & 99.2 \\
\hline TRICAL & FO & 27.8 & 122 & 8.41 & 2.58 & 357.9 & 650.7 & 616.4 & 335.9 & 41.6 & 85.0 & 94.9 \\
\hline NE422T & FO & 27.4 & 120.0 & 9.23 & 3.27 & 347.4 & 655.8 & 597.4 & 324.9 & 38.9 & 82.9 & 99.8 \\
\hline Wheat $^{\ddagger}$ & & 20.6 & 148.0 & 7.92 & 2.95 & 373.1 & 644.9 & 600.0 & 324.3 & 39.9 & 83.7 & 100.0 \\
\hline Mean & & 21.7 & 109.5 & 9.29 & 3.8 & 380.2 & 650.2 & 604.6 & 328.1 & 40.3 & 84.6 & 98.0 \\
\hline LSD (.05) & & 0.77 & 3.35 & ns & 0.4 & 0.56 & ns & 6.4 & ns & 0.7 & ns & ns \\
\hline $\mathrm{CV}$ & & 3.6 & 3.8 & 14.6 & 13.2 & 8.04 & 3.52 & 5.76 & 6.89 & 9.73 & 10.83 & 8.39 \\
\hline
\end{tabular}

†Type of cultivar based on visual assessment. GR, grain type; FO, forage type; GR/FO, grain type with spring forage potential.

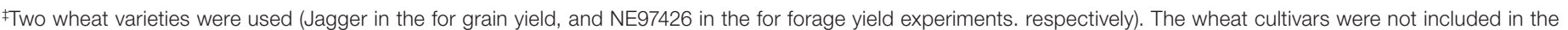
overall analysis.

The difference in agronomic and quality traits of strains observed suggest a wide range of diversity among triticale strains for forage and grain yield and for forage quality. The two Nebraska released cultivars (NE422T and NE426GT) still performed better than most of the experimental strains suggesting that more breeding progress or work is needed to develop new strains with greater grain and forage yield (Fig. 3; Table 5). Most of the visually classified grain-type strains were of intermediate maturity, while most of the visually classified forage-type strains were later maturing and lower in grain yield. Thus it seems lateness, though it can lead to increased forage yield or forage availability at a different time of year when it may be most needed, comes at the expense of grain yield. The increased grain formation in early maturing strains may have contributed to increased forage weight and digestibility (IVDMD) because all strains were harvested at the same time. Late maturing strains could be more desirable due to their potential to provide forage in the late spring. Rao et al. (2000) in their 4-yr study observed that late maturing forage species produced less biomass, but continued to accumulate biomass after the early genotypes had matured. Varieties with different maturities can also complement each other because forage availability and what individual producers have for native forages, or crop residues varies with individual operations.
Three experimental strains were among the top 10 entries for both forage and grain yield (Table 5, Fig. 3), hence progress toward developing cultivars with both good grain and forage production potential has been made. This result indicated that some of the grain type strains have good potential to provide forage in early spring. Trical, one of the oldest triticale cultivars, was among the three lowest strains for both forage yield and grain yield (8.41 and $2.58 \mathrm{Mg} \mathrm{ha}^{-1}$, respectively), indicating progress made in triticale improvement over the past 20 years.

Since there were highly significant differences for locations and year $\times$ location for most traits, correlations were determined for each location separately. At Sidney, there were no significant correlations between agronomic traits $(P<0.05)$, while at Mead some agronomic traits showed significant correlations (Table 6), therefore the following statements apply to Mead only. The later flowering strains were lower in grain yield $(r=-0.73, P<0.01)$, but not necessarily lower in forage yield $(r=-0.27$, not significant) when compared to the early flowering ones (Table 6). There was no significant correlation between plant height and forage yield $(r=0.042)$, but plant height was correlated with grain yield ( $r=-0.437, P<0.05$; Table 6$)$, thus tall strains didn't necessarily make good forage triticale strains. Agronomic traits were not significantly correlated to most quality traits (Table 6). The correlation analysis of 
combined data of both locations and years showed a similar trend (data not shown) with nonsignificant correlation between plant height and forage yield $(r=-0.134)$, a highly significant correlation between plant height and grain yield $(r=-0.668$, $P<0.001)$, and all agronomic traits were not significantly correlated with the quality traits. These results indicated that it is not possible to select for forage quality using agronomic traits such as maturity, grain yield, and height.

In summary, this study has shown that triticale forage harvested as a hay crop in the Central Great Plains has acceptable quality for use by beef cattle production herds. Triticale maintains good forage yield and quality across diverse Central Plains environments and over years. There are some new triticale strains (e.g., NT02454 and NT02421) that can perform similarly or better than the best available cultivars (e.g., NE422T and NE426GT) for both grain and forage production. In addition, NT02419, which had excellent grain yield and forage yield, had very good forage quality as indicated by relative feed value. Visual classifications used for selecting better forage production with good grain yield, forage yield, and quality were ineffective because the agronomic traits showed little or no correlation to forage yield and forage quality. However, most of the intermediate maturing strains used in the study seemed to have both grain and forage yield without compromising quality.

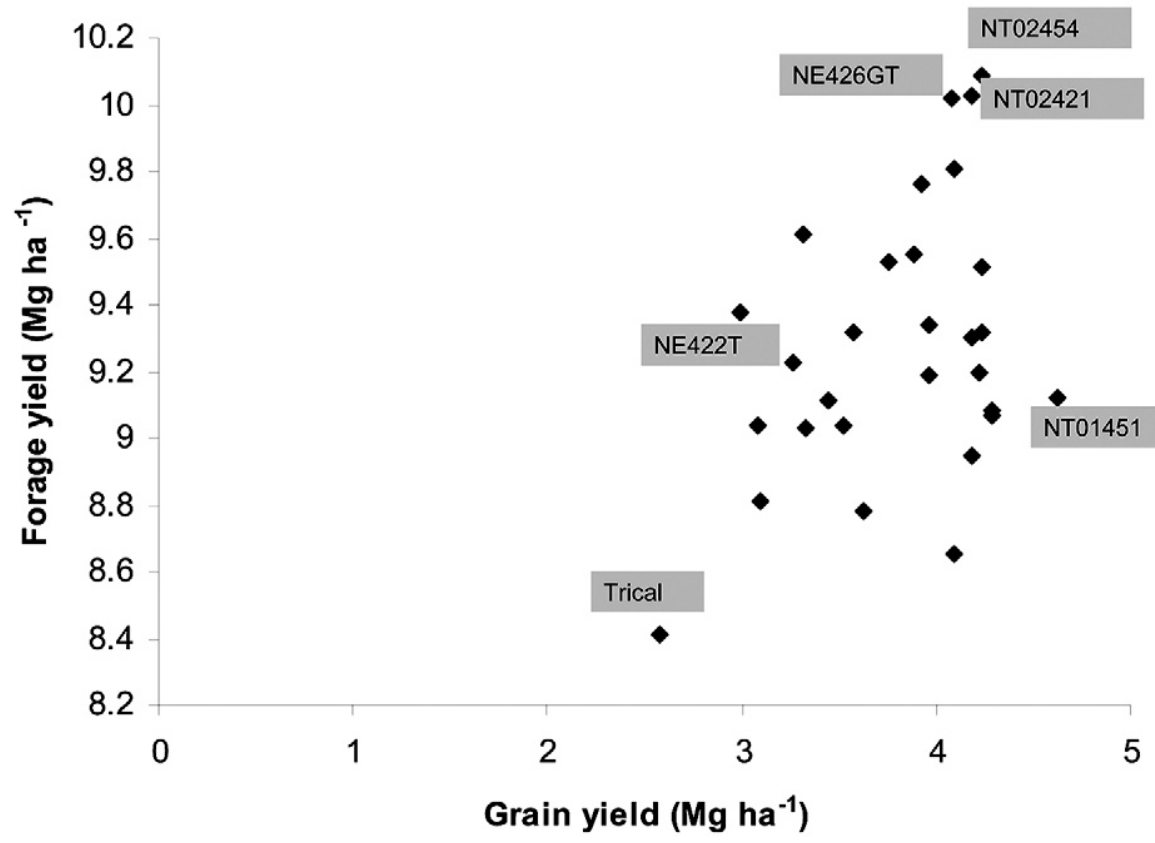

Figure 3. Relationship between forage yield and grain yield for 29 triticale cultivars and strains. The data points that are labeled are check cultivars and cultivars or strains that had both good forage and grain yields at Mead and Sidney, NE, in 2003-2004 and 2004-2005 seasons (significant $r=0.39, P<0.05$ ).

\section{Acknowledgments}

We wish to express our gratitude to wheat program personnel for assistance with plant population management and to $\mathrm{Mr}$. Steve Masterson for assistance with forage quality analysis. This work was partially funded by the Botswana Government under Ministry of Agriculture student's scholarship.

\section{References}

Adesogan, A.T. 2002. What are feeds worth? A critical evaluation of selected nutritive value methods. p. 33-47. In Proc. 13th Annual Florida Ruminant Nutrition Symp., Gainesville, FL. 11-12 Jan 2002. Univ. of Florida, Gainesville.

Table 6. Trait correlations for strain means of triticale grown at Mead and Sidney, NE. The correlations for Mead are above the diagonal, and those of Sidney are below the diagonal $(n=29)$. Flowering date (FD), plant height $(H T)$, forage yield $(F Y)$, grain yield (GY), dry matter (DM), in vitro dry matter digestibility (IVDMD), neutral detergent fiber (NDF), acid detergent fiber (ADF), acid detergent lignin (ADL), crude protein (CP) concentration, and relative feed value (RFV).

\begin{tabular}{|c|c|c|c|c|c|c|c|c|c|c|}
\hline & HT & FY & GY & DM & IVDMD & NDF & ADF & ADL & $\mathrm{CP}$ & RFV \\
\hline$\overline{F D}$ & $0.733^{* *}$ & -0.274 & $-0.732^{\star \star}$ & $-0.764^{\star \star}$ & 0.230 & -0.197 & -0.191 & $-0.316^{\dagger}$ & 0.000 & 0.199 \\
\hline HT & & 0.042 & $-0.437^{*}$ & $-0.550^{\star \star}$ & 0.025 & 0.035 & 0.071 & -0.037 & -0.039 & -0.030 \\
\hline FY & 0.119 & & $0.419^{*}$ & 0.237 & $-0.348^{\dagger}$ & $0.324^{\dagger}$ & $0.316^{\dagger}$ & $0.402^{*}$ & 0.005 & -0.299 \\
\hline GY & 0.129 & $0.359^{\dagger}$ & & $0.534^{* *}$ & -0.278 & 0.308 & 0.292 & $0.340^{\dagger}$ & 0.027 & -0.301 \\
\hline DM & -0.074 & -0.002 & 0.225 & & -0.250 & 0.299 & 0.271 & $0.440^{*}$ & 0.171 & -0.305 \\
\hline IVDMD & 0.224 & 0.230 & -0.032 & $-0.316^{\dagger}$ & & $-0.845^{\star \star}$ & $-0.867^{\star \star}$ & $-0.704^{\star \star}$ & 0.092 & $0.839^{\star \star}$ \\
\hline NDF & $-0.334^{\dagger}$ & -0.168 & -0.008 & -0.027 & $-0.474^{\star \star}$ & & $0.993^{\star \star}$ & $0.915^{\star \star}$ & 0.228 & $-0.998^{\star *}$ \\
\hline ADF & -0.255 & -0.166 & -0.012 & -0.051 & $-0.469^{*}$ & $0.968^{\star \star}$ & & $0.900^{\star \star}$ & 0.161 & $-0.993^{\star *}$ \\
\hline ADL & -0.297 & -0.034 & 0.096 & -0.149 & -0.080 & $0.783^{* *}$ & $0.765^{\star \star}$ & & 0.311 & $-0.919^{\star \star}$ \\
\hline $\mathrm{CP}$ & -0.093 & 0.027 & -0.037 & 0.046 & $0.520^{\star \star}$ & 0.033 & -0.085 & 0.061 & & -0.210 \\
\hline RFV & 0.310 & 0.172 & -0.004 & 0.061 & $0.485^{\star \star}$ & $-0.995^{\star \star}$ & $-0.979^{\star \star}$ & $-0.782^{\star \star}$ & 0.009 & \\
\hline
\end{tabular}

*Significant at the 0.05 probability level.

**Significant at the 0.01 probability level.

†Significant at the 0.10 probability level. 
Association of Official Agricultural Chemists. 1960. Official methods of analyses of the AOAC. 9th ed. AOAC, Washington, DC.

Baenziger, P.S., J.-L. Jannink, and L.R. Gibson. 2005. Registration of 'NE426GT' winter triticale. Crop Sci. 45:796-797.

Baenziger, P.S., and K.P. Vogel. 2003. Registration of 'NE422T' winter triticale. Crop Sci. 43:434-435.

Bremmer, J.M. 1996. Nitrogen: Total. p. 1085-1121. In D.L. Sparks et al. (ed.) Methods of soil analysis. Part 3. Chemical methods. SSSA Book Ser. 5. ASA and SSSA, Madison, WI.

Carmer, S.G. 1976. Optimal significance levels of application of the least significant difference in crop performance trials. Crop Sci. 16:95-99.

Fufa, H., P.S. Baenziger, B.S. Beecher, R.A. Graybosch, K.M. Eskridge, and L.A. Nelson. 2005. Genetic improvement trends in agronomic performances and end-use quality characteristics among hard red winter wheat cultivars in Nebraska. Euphytica 144:187-198.

Gomez, A.K., and A.A. Gomez. 1984. Statistical procedures for agricultural research. p. 330-332. John Wiley \& Sons, New York.

Harmoney, K.R., and C.A. Thompson. 2005. Fertilizer rate and placement alters triticale forage yield and quality. Available at www.plantmanagementnetwork.org/pub/fg/research/2005/ fertilizer/. Forage Grazinglands.

Hede, A.R. 2001. A new approach to triticale improvement. p. 21-26. In Research highlights of the CIMMYT wheat program, 1999-2000. CIMMYT, Mexico, D.F.

Lardy, G.P., D.C. Adams, T.J. Klopfenstein, and H.H. Patterson. 2004. Building beef cow nutritional programs with the 1996 NRC beef cattle requirements model. J. Anim. Sci. 82(Suppl.):E83-E92.

McDonald, P., R.A. Edwards, J.F.D. Greenhalgh, and C.A. Morgan. 1995. Animal nutrition. 5th ed. Pearson Education Ltd., Edinburgh Gate, Harlow Essex, UK.

Mitchell, R.B., K.P. Vogel, T.J. Klopfenstein, B.E. Anderson, and R.A. Masters. 2005. Grazing evaluation of big bluestems bred for improved forage yield and digestibility. Crop Sci. 45:2288-2292.

Moore, J.E., and D. Undersander. 2002. Relative forage quality: An alternative to relative feed value and quality index. p. 1-32. In Proc. 13th Annu. Florida Ruminant Nutrition Symp., Gainesville, FL. 11-12 Jan 2002. Univ. of Florida, Gainesville.

Nance, C.D., L.R. Gibson, and D.L. Karlen. 2007. Soil profile nitrate response to nitrogen fertilization of winter triticale. Soil Sci. Soc. Am. J. 71:1343-1351.

National Research Council. 1996. Nutrient requirement of beef cattle. National Academy Press, Washington, DC.

Peterson, C.J. 1992. Similarities among test sites based on cultivar performance in the hard red winter wheat region. Crop Sci. 32:907-912.
Peterson, C.J., R.A. Grabosch, P.S. Baenziger, and A.W. Grombacher. 1992. Genotype and environment effects on quality characteristics of hard red winter wheat. Crop Sci. 32:98-103.

Rao, S.C., S.W. Coleman, and J.D. Volesky. 2000. Yield and quality of wheat, triticale, and elytricum in the southern plains. Crop Sci. 40:1308-1312.

Rohweder, D.A., R.F. Barnes, and N. Jorgensen. 1978. Proposed hay grading standards based on laboratory analyses for evaluating quality. J. Anim. Sci. 47(3):747-759.

Sapra, V.T., G.C. Sharma, J. Hughes, and R.R. Bradford. 1973. Triticale, a wheat-rye hybrid. J. Tenn. Acad. Sci. 48:59-61.

SAS Institute. 1996. SAS/STAT user's guide. Version 6, 4th ed. Vol. 1-2. SAS Inst., Cary, NC.

Schwarte, A. J., L.R. Gibson, D. L. Karlen, M. Liebmann, and J.-L. Jannink. 2006b. Planting date effects on winter triticale dry matter and nitrogen accumulation. Agron. J. 97:1333-1341.

Schwarte, A.J., L.R. Gibson, D.L. Karlen, P.M. Dixon, M. Liebmann, and J.-L. Jannink. 2006a. Planting date effects on winter triticale grain yield and yield components. Crop Sci. 46:1218-1224.

Shenk, J.S., and M.O. Westerhaus. 1991. Population definition, sample selection, and calibration procedures for near infrared reflectance spectroscopy. Crop Sci. 31:469-474.

Van Soest, P.J. 1982. Nutritional ecology of the ruminant: Ruminant metabolism, nutritional strategies, the cellulolytic fermentation and the chemistry of forages and plant fibers. O \& B Books, Corvallis, OR.

Van Soest, P.J., D.R. Mertens, and B. Deinum. 1978. Preharvest factors influencing quality of conserved forage. J. Anim. Sci. 47(3):712-720.

Varughese, G., W.H. Pfeiffer, and R.J. Pena. 1997. Triticale: A reappraisal. Available at www.worldbank.org/html/cgiar/ newsletter/april97/8tritic.html (verified 8 Aug. 2008). CGIAR News 4(2):7, 15, 17-18.

Vogel, K.P., J.F. Pedersen, S.D. Masterson, and J.J. Toy. 1999. Evaluation of a filter bag system for NDF, ADF, and IVDMD forage analysis. Crop Sci. 39:276-279.

Vogel, K.P., P.E. Reece, and J.F.S. Lamb. 1986. Genotype and genotype $\times$ environment interaction effects for forage yield and quality of intermediate wheatgrass. Crop Sci. 26:653-658.

Vogel, K.P., P.E. Reece, and J.T. Nichols. 1993. Genotype and genotype $\times$ environment interaction effects on forage yield and quality of intermediate wheatgrass in swards. Crop Sci. 33:37-41.

Watson, M.E., and R.A. Isaac. 1990. Analytical instruments for soil and plant analysis. p.691- 704. In R.L. Westerman (ed.) Soil testing and plant analysis. 3rd ed. SSSA Book Ser. 3. SSSA, Madison, WI. 